\title{
Türkiye Afet Bilgi Bankası (TABB) ile EM-DAT Veri Tabanlarının Karşılaştırılarak Değerlendirilmesi
}

\author{
Comparative Evaluation on Disaster Knowledge Bank of Turkey (TABB) and the EM-DAT Database
}

\section{Can SAHAN}

Öğr. Gör. Amasya Üniversitesi, Suluova MYO,

Mülkiyet Koruma ve Güvenlik Bölümü,

can.sahan@amasya.edu.tr

https://orcid.org/0000-0002-9086-9062

\author{
İsmail KAYA \\ Öğr. Gör. Amasya Üniversitesi, Suluova MYO, \\ Mülkiyet Koruma ve Güvenlik Bölümü, \\ ismailkaya1611@gmail.com \\ https://orcid.org/0000-0001-5948-0043
}

Makale Başvuru Tarihi: 14.04.2021

Makale Kabul Tarihi: 06.11.2021

Makale Türü: Araştırma Makalesi

\section{ÖZET}

Afet risk yönetimi kapsamında strateji gelişstirmeye yönelik ilk adım, mevcut durumun analiz edilmesidir. Mevcut durumun analiz edilebilmesi için çeșitli veri setlerine ihtiyaç duyulmaktadır. Çeşitli veri setleri sayesinde, risk analizlerinin yaplmast ile karar vericiler ve uygulayıcılar tarafindan politika ve stratejilerin belirlenmesi daha kolay hale gelmektedir. Öte yandan bu veri setlerine tek elden ulaşmak da çok önemlidir.

Anahtar

Kelimeler:

Afet,

Afet Yönetimi,

Afet Veri Tabanı,

$T A B B$,

$E M-D A T$

Keywords:

Disaster,

Disaster

Management,

Disaster Database,

$T A B B$,

EM-DAT, Çünkü çok farklı kurumlar tarafından kayıt altına alınan verilerle çalışmalar yapmak araştırmacıların gözünde büyümekte ve doğru veriye ulaşım zorlaşmaktadır. Tüm bu problemlerin giderilmesi amacıyla Türkiye Afet Bilgi Bankası oluşturulmuştur. Çalışmada uluslararası alanda en fazla atıf alan veri tabanlarından bir tanesi olan EM-DAT ile TABB veri tabanları temel özellikler bakımından karşılaştırılarak güçlü ve zayıf yönleri araştırma kapsamında ortaya konmaya çalışılmıştır. Aynı zamanda TABB veri tabanının güvenirliği de çalışma ile ortaya konulmaya çalışılmıştır. Sonuç olarak TABB veri tabanı için yapılan değerlendirmede, geniş yelpazede afet ve acil durumlart ve bunların özelliklerini kayıt altına alması ayrıca kayıt için herhangi bir kriterin olmaması kapsamlı risk analizlerinin yapılmasına olanak sağladiğı söylenebilir. Farklı türlerde afet ve acil durumların kayıt altına alınması önemli olduğu kadar bunların veri tabanına eksiksiz şekilde girilmesi de bir o kadar önemlidir. Ancak 2010-2020 yılları arasında ülkemizde meydana gelen depremlerin bilgileri EM-DAT veri tabanı tarafindan girilmesine rağmen TABB veri tabanı tarafindan girişlerin yapılmadığı tespit edilmiştir. Bu da yapılan çalışmaların güvenirliğini etkileyerek karar vericilerin ve uygulaylcıların afet ve acil durumlar için afet risk yönetimi kapsamında yanlış stratejiler geliştirmesine neden olabileceği düşünülmektedir. Bu bağlamda çalışma kapsamında öneriler geliştirilerek sonuç bölümünde listelenmiştir.

\section{ABSTRACT}

The first step towards developing a strategy within the scope of disaster risk management is to analyze the current situation. Various data sets are needed to analyze the current situation. Thanks to various data sets, it becomes easier to determine policies and strategies by decision makers and practitioners with risk analysis. On the other hand, it is also very important to access these data sets from a single source. Because working with data recorded by many different institutions grows in the eyes of researchers and accessing the right data becomes difficult. Turkey in order to overcome all these problems Disaster Data Bank was created. In the study, EM-DAT, which is one of the most cited databases in the international arena, and TABB databases were compared in terms of their basic features and their strengths and weaknesses were tried to be revealed within the scope of the research. At the same time, the reliability of the TABB database has been tried to be revealed by the study. As a result, it can be said that in the evaluation made for the TABB database, it can be said that recording a wide range of disasters and emergencies and their characteristics, and the absence of any criteria for recording, enables a comprehensive risk analysis. It is important to record different types of disasters and emergencies, as well as to enter them completely into the database. However, it was determined that the data of earthquakes that occurred in our country between 2010-2020 were entered by the EM-DAT database, but not entered by the TABB database. It is thought that this may affect the reliability of the studies and cause decision-makers and practitioners to develop wrong strategies within the scope of disaster risk management for disasters and emergencies. In this context, recommendations were developed within the scope of the study and listed in the conclusion section. 


\section{GIRISS}

Tarihsel olarak dünyada ve ülkemizde afetlerle başa çıkmada kriz yönetimi odaklı bir afet yönetim anlayışı benimsenmiştir. Ancak 20. yüzyılın sonlarına doğru afet risk yönetimi anlayışı kapsamında afet risk azaltmaya doğru bir dönüşüm başlamıştır. Afet risk yönetimi ile afet risk azaltma kavramları karıştırılarak birbiri yerine kullanılabilmektedir. Afet risk yönetimi riski azaltma hedefine ulaşmayı amaçlayan eylemleri tanımladığından afet risk azaltmanın uygulaması olarak düşünülebilir. Afet risk azaltma ise, afetlerin doğal olmadığı temelinden hareketle tehlike, maruz kalma ve savunmasızlık koşullarını azaltarak ve yöneterek kayıpları önleyip afetlerin etkilerinin hafifletilmesi şeklinde açıklanabilir. Ancak doğal tehlikelerin önlenmesi mümkün olmaması nedeniyle risk azaltma kapsamında temel yaklaşım, doğal tehlikeler için savunmasızlı̆̆ ve maruziyeti azaltmaktır. Bu iki risk bileşenini azaltmak için tehlike, maruz kalma ve savunmasızlık koşullarını yaratan ve şiddetlendiren özellikle zayıf ekonomik ve kentsel kalkınma tercihleri ve uygulamaları, çevrenin bozulması, yoksulluk ve eşitsizlik ve iklim değişikliği ile ilgili olan riskin altında yatan etmenlerin tanımlanmasını ve azaltılmasını gerektirir. Altta yatan bu risk faktörlerinin ele alınması afet riskini, iklim değişikliğinin etkilerini azaltacak ve sonuç olarak kalkınmanın sürdürülebilirliğini koruyacaktır (UNDRR, 2015).

Afet risklerinin analiz edilebilmesi için tehlike hakkında bilgi sahibi olmamız gerekmektedir. Bunun içinde geçmişte meydana gelmiş ve çeşitli kaynaklar tarafından kayıt altına alınmış afet verilerine ihtiyaç bulunmaktadır. Bu sayede deneyimlerin ve sonuçların kaybolmadan gelecek nesillere aktarımı sağlanmış olacaktır (Hamzaçebi vd., 2007:174). Araştırmacılar tarafından afetlerle ilgili bu bilgi birikimine daha kolay ve daha hızlı erişimin sağlanması ve farklı veri setlerini kullanarak analizler yapılabilmesi için verilere tek elden ulaşılması da büyük önem arz etmektedir. Bu amaçla ulusal ve uluslararası alanda oluşturulmuş veri tabanları bulunmaktadir.

Afet veri tabanlarının kayıt altına almış olduğu bilgilerin tutarlı olması araştırmacılar tarafından yapılacak çalışmaların da güvenilir olmasını sağlayacağı düşünülmektedir. Yüksek kaliteli doğal afet analizlerinin yapılabilmesini sağlamak için verilerin yüksek derecede uzmanlık ve profesyonellikle toplanması, kontrol edilmesi ve yönetilmesi gerekmektedir (Wirtz vd., 2014:135). Araştırmada, "Afet sonrası ortaya çıkan mevcut durumun farklı kaynaklardan duyurulması ve çeşitli veri tabanlarına aktarılması konusunda tutarsızlıkların olması güvenilir ve doğru bilgiye erişim konusunda özellikle araştırmacılar için sorun yaratmakta mıdır?", problemine çözüm aranmaktadır. Bu çalışmanın temel amacı, ülkemizde en fazla can ve mal kaybına neden olan depreme ilişkin EM-DAT afet veri tabanı ile ülkemizde oluşturulmuş Türkiye Afet Bilgi Bankası veri tabanının kendine has özellikleri ve bildirdiği verilerin benzerliklerini ve farklılıklarını karşılaştırmak ve derinlemesine incelemektir. Bu sayede afet veri tabanlarının güçlü ve zayıf yanları ve test yayını olan TABB veri tabanının güvenirliği ortaya konulmaya çalışılmıştır.

Çalışma nitel bir araştırma olup doküman analizi kullanılmıştır. Wach'a (2013) göre, basılı kaynakların içeriğini derinlemesine ve sistemsel olarak incelemek için tercih edilen bir nitel araştırma yöntemidir (Wach, 2013:1). Çalışmada herkese açık ikincil veriler kullanıldığı için etik kurul onayı gerektirmemektedir. Çalışma iki bölümde planlanmıştır. Birinci bölümde kavramsal ve kuramsal çerçeveye, EM-DAT veri tabanına ve TABB veri tabanına yer verilmiş olup veri tabanları ayrıntılı şekilde sunulmuştur. İkinci bölümde ise iki veri tabanının bildirdiği bilgilerin benzerlikleri ve farklılıkları karşılaştırılarak incelenmiştir. Karşılaştırma iki şekilde gerçekleştirilmiştir. Birinci karşılaştırma iki veri tabanının temel özellikleri (kuruluş, kapsam, metodoloji, afet türleri, dahil edilme kriterleri, veri başlıkları, veri kaynakları, erişim, glide numarası, veri arama yöntemi, grafik oluşturma, harita oluşturma ve sözlük) karşılaştırılarak aralarındaki benzerlikler ve farklılıklar saptanmıştır. Bu karşılaştırma iki veri tabanı tarafından kullanılan veri tanımlama, toplama ve işleme yöntemleri, kayıtlardaki olası farklılıkları anlamamıza ve yorumlamamıza yardımcı olması anlamında önemlidir. Bu karşılaştırma ile veri tabanlarının güçlü ve zayıf yönleri ortaya koyulmaya çalışılmıştır. İkinci karşılaştırma ise 2010-2020 yılları arasında 10 yılı kapsayan 81 ilde meydana gelen depremlerde iki veri tabanı tarafından kaydedilen istatistikî bilgiler zamansal ve mekânsal olarak karşılaştırılmıştır. Bu karılaştırma deprem olayının ölüm ve yaralanma sayısı olmak üzere iki hasar göstergesi kategorisi dikkate alınarak yapılmıştır. Bu sayede test yayını olan TABB veri tabanının güvenirliği ortaya konulmaya çalışılmıştır. 


\section{KAVRAMSAL VE KURAMSAL AÇIDAN AFET VE AFET YÖNETIMI}

Afet kavramı, "insanlar için can, fiziksel, ekonomik ve sosyal kayıplara neden olan, normal yaşamı durdurarak veya kesintiye uğratarak toplumları etkileyen ve yerel imkânlar ile baş edilemeyen her türlü doğal, teknolojik veya insan kaynaklı olaylar", olarak tanımlanmaktadır (UN, 1992:27). Birleşmiş Milletler (BM) Uluslararas1 Doğal Afetleri Azaltma Stratejisi (UNISDR) çerçevesinde afet, "yaygın insani, maddi, ekonomik veya çevresel kayıplart içeren bir topluluğun veya bir toplumun işleyişinde ciddi bir bozulma ve etkilenen topluluğun veya toplumun kendi kaynaklarını kullanarak başa çıkma becerisini aşan etkilerdir", olarak kavramlaştırılmıştır (UNISDR, 2009:9).

Literatürde afetler genellikle doğal ve insan kaynaklı afetler olmak üzere iki başlık altında sınıflandırılmaktadır. Doğal kaynaklı afetler doğa olayları sonucunda meydana gelen afetlerdir. Yağmurun yağması sonucu sellerin oluşması buna örnek olarak verilebilir. Seli afet olarak değerlendirebilmemiz için toplumun gündelik yaşamını kesintiye uğratması veya durdurması, neden olduğu kayıp ve zararların yerel imkânlarla önlemenin mümkün olmaması ve dişarıdan yardıma ihtiyaç olması gerekmektedir (Keçici, 1994:24). Bu bağlamda ülkemizde meydana gelen doğa olayları ise deprem, heyelan, sel, kaya düşmesi, çı̆̆ ve orman yangınları olarak sıralanmaktadır (Kundak ve Kadıoğlu, 2011:5). İnsan kaynaklı afetler ise doğrudan insanların neden olduğu afetler olarak söylenebilir (Gökçekuş vd., 2018:3). Doğal kaynaklı afetlerde olduğu gibi insan kaynaklı afetlerde de büyük çapta yaralanmalara ve ölümlere neden olmakta, toplumsal yaşama ve çevreye büyük zararlar verebilmektedirler. Bazı kaynaklarda ise bu sınıflandırmaya karma afetler başlı̆̆ da eklenmektedir. Yangınlar karma afetler başlı̆ğ altında değerlendirilebilmektedir. Çünkü yangınlar hem doğa kaynaklı hem de insan kaynaklı meydana gelebilmektedir (Işık vd., 2012:85).

Kaynağı ne olursa olsun her olayı afet olarak değerlendirmek pek mümkün değildir. Bir olayı afet olarak değerlendirebilmek için insanlara ve insanların yaşadığı alanlara zarar vermesi, kayıplara neden olması ve insan faaliyetlerini durdurması veya kesintiye uğratması gerekmektedir. Dolayısıyla insanların ve yaşam alanlarının bir tehlikeye maruz kalmadığı sürece afetlerin oluşma ihtimali yoktur (Yavaş, 2005:10). Ancak afetten söz edebilmek için maruziyet de tek başına yeterli olmamaktadır. Aynı zamanda bireylerin, toplumun ve devletin afetler karşısında zayıf yönlerini temsil eden savunmasızlık faktörüne de ihtiyaç vardır. Afetler, savunmasız bir nüfusun bir tehlikeye maruz kalması ve olumsuz etkilenmesi durumunda meydana gelmektedir. Bireylerin, toplumların ve devletlerin ne kadar savunmasız olduğunu belirlemede temel yapı taşı tehlikelere karşı ne kadar dirençli olduğu ile alakalıdır (Cannon, 2006:45).

Afet sonrasında meydana gelecek can ve mal kaybının boyutu meydana gelen olayın şiddetinin yanı sıra toplumun zarar görebilirliği ile de yakından ilişkilidir. Afetten söz edebilmek için bir bölgede tehlikenin var olması bunun yanında o tehlikeye insan ve değerlerinin maruz kalmaları ve aynı zamanda tehlike karşısında savunmasız durumda olmaları gerekmektedir. Burada maruziyet ve savunmasızlıkla ifade edilmek istenen şey aslında zarar görebilirliktir (Taştan ve Aydınoğlu, 2015:368; Özceylan ve Çoşkun, 2012:169; Güler, 2008:38).

Afet yönetiminin kapsamını, afet meydana gelmeden önce afetlerin önlenmesi için yapılan çalışmalar ve hazırlığı, afet meydana geldikten sonra ise hızlı ve etkin bir müdahale ve eskiye dönüş için iyileştirme faaliyetleri oluşturmaktadır. Afet yönetiminin amaçlarına değinilecek olursa mümkün oldukça olası tehlikelerden uzak durarak afetleri önlemek mümkün değilse vereceği zararları azaltmak, bütün önlemlere rağmen afet meydana geldiğinde hızlı ve etkin bir müdahaleyle acil yardım veya uygun yardımı sağlamak ve son olarak kalıcı ve hızlı bir iyileştirme çalışmasını yapmak olarak söylenebilir (Sena ve Woldmichael, 2006:113). Afet öncesinde yapılan çalışmalar risk yönetimi olarak adlandırılırken afet anında ve sonrasında yapılan çalışmalar ise kriz yönetimi olarak adlandırılmaktadır. Risk yönetimi risk azaltma ve hazırlık evrelerinden oluşurken, kriz yönetimi ise müdahale ve iyileştirme evrelerinden oluşmaktadır (Kadıoğlu, 2011:51; Özmen ve Özden, 2013:4; Erkal ve Değerliyurt, 2009:151).

Potansiyel bir afetin etkisini azaltmak için afet yönetiminin ilk ve en önemli evresi risk ve zarar azaltmadır. Risk ve zarar azaltma aşaması uzun süreçte, tehlikeler ve bunların etkileri sonrası meydana gelebilecek can ve mal kaybı zararlarını azaltmayı veya önlemeyi amaçlayan sürekliliği olan faaliyetleri kapsamaktadır. Hazırlık evresi ise afetler karşısında baş edebilme kapasitesinin arttırılması için gerçekleştirilen faaliyetler olarak söylenebilir. Hazırlık, herhangi bir afet meydana geldiğinde can ve mal kaybının en az seviyede tutulması ve afet öncesi hayata dönüşün hızlı olmasının sağlanması amacıyla afet öncesinde yapılan çalışmaları içerir. Bir afet meydana geldiğinde muhtemel kayıpların ve tehlikelerin bertaraf edilmesi, yardıma ihtiyacı olanların tespit edilmesi ve kurtarılması, acil yardım ihtiyaçlarının karşılanması ve arama ve kurtarma konularında kapasitenin geliştirilmesi hazırlık evresi kapsamında yapılan çalışmalardır. Müdahale ve iyileştirme aşamalarının başarılı olmasını risk 
ŞAHAN, Can ve KAYA, İsmail - Türkiye Afet Bilgi Bankası (TABB) ile EM-DAT Veri Tabanlarının Karşılaştırılarak Değerlendirilmesi

yönetimi kapsamında yapılan çalışmalar belirlemektedir (Akyel, 2007:36; Kadıŏlu, 2008:11; Kadığlu, 2011:18).

Ülkemiz gelişmekte olan bir ülke olması nedeniyle afetler sonrasında hem can kaybı hem de maddi kayıp açısından çok fazla miktarda etkilenmektedir. Bu etki düzeyi şehirleşmeyle daha da artmış ve artmaktadır. Ülkemizde birçok şehir, bir veya birden çok doğal kaynaklı afet riski altındadır (Kundak ve Kadığlu, 2011:5). Tablo 1'e bakıldığında 1950 - 2008 yılları arasında ülkemizde meydana gelen afetlerin sayısı, afetzede sayısı ve zarar gören yerleşim birimi sayısı gösterilmektedir. Bu tabloya göre ülkemizde insanları en fazla etkileyen doğal kaynaklı afetler; deprem, heyelan, sel, kaya düşmesi, çığ ve diğer afetler olarak sıralanmaktadır (Gökçe vd., 2008:118).

Tablo 1. Ülkemizde Meydana Gelen Afetlerle İlgili İstatistikler

\begin{tabular}{|c|c|c|c|c|}
\hline Afet Türü & $\begin{array}{c}\text { Afetzede Sayısı } \\
(\text { Kişi) }\end{array}$ & $\begin{array}{c}\text { Afetzede Sayısı } \\
(\mathbf{\%})\end{array}$ & Afet Olay Sayısı & $\begin{array}{c}\text { Zarar Gören } \\
\text { Yerleşim Yeri Sayısı }\end{array}$ \\
\hline Deprem & 158.241 & $\% 58$ & 5.318 & 3.942 \\
\hline Heyelan & 59.345 & $\% 22$ & 13.494 & 5.472 \\
\hline Su Baskını & 22.157 & $\% 8$ & 4.067 & 2.924 \\
\hline Kaya Düşmesi & 19.422 & $\% 7$ & 2.956 & 1.703 \\
\hline Çı̆̆ & 4.384 & $\% 2$ & 731 & 605 \\
\hline Diğer Afetler & 9.237 & $\% 3$ & 1.175 & 992 \\
\hline Toplam & $\mathbf{2 7 2 . 7 8 6}$ & $\mathbf{\% 1 0 0}$ & $\mathbf{2 7 7 3 5}$ & $\mathbf{1 5 . 6 3 8}$ \\
\hline
\end{tabular}

Kaynak: Gökçe vd., 2008:118.

2015 ile 2030 yıllarını kapsayan Sendai Çerçeve Eylem Planı ile planların yapılması ve risklerin azaltılması amacıyla dört öncelik belirlenmiştir. Bu öncelikler şunlardır (UNDRR, 2015);

- Afet riskini anlamak

- Afet riskini yönetmek için afet riski yönetişiminin güçlendirilmesi

- Dirençlilik için afet riskinin azaltılmasına yatırım yapmak

- Etkili müdahale için afete hazırlık çalışmalarını geliştirmek ve iyileştirme, rehabilitasyon ve yeniden inşa safhalarında " Öncekinden Daha İyisini İnşa Etmek".

Görüldüğü gibi risklerin azaltılması ve önlenmesinde önceliklerden bir tanesi risklerin anlaşılmasıdır. Bu bakımdan afetlerin meydana getireceği zararların önlenmesi veya azaltılması konusunda toplumun tüm kesimleri tarafından yaşadıkları bölgede olası tehlikelerin neler olduğunun ve bu tehlikeler ortaya çıktığında ne gibi hasarlara neden olabileceğinin bilinmesi büyük önem arz etmektedir (İlgen, 1995:91). Afet risklerini anlamak amacıyla gerçekleştirilen risk analizleri kapsamında ilk yapılması gereken tehlkelerin belirlenmesidir (Çolak, 2017:76). Tehlikeler belirlendikten sonrada bu tehlikelerin olasıllk ve şiddet parametrelerini kullanarak risklerin seviyeleri belirlenebilir. Bunun için de geçmişte meydana gelmiş afet ve acil durumların kayıtlarına ihtiyaç duyulmaktadır. Çünkü bu kayıtlar yaşanan afetlerin sıklık, dağılım ve değişimlerini incelenmek suretiyle, alınacak önlemlerin belirlenmesinde yardımcı olmaktadır. Afet ve acil durumların kayıtlarının tutulması için ise afet bilgi sistemlerine ihtiyaç bulunmaktadır.

Doğal kaynaklı afet veri tabanlarının geliştirilmesi, risk yönetimi amaçları için kesinlikle belirleyicidir (Dankers vd., 2007:168). Günümüzde önemi gittikçe artan risk/zarar azaltma ve afete hazırlık çalışmalarında araştırmacıların ve karar vericilerin istediği anda ulaşabileceği yakınlıkta olması gereken bilgiler arasında, yaşanmış afet olaylarına ait bilgi birikimi de bulunmalıdır. Her düzeyde karar vericiler, araştırmacılar, yöneticiler ve halk politika, strateji ve yaklaşımlarını bu bilgi birikimi üzerine kurgulamak zorundadır (Li vd., 2018:46; Guha-Sapir vd., 2004:18).

Afet riski araştırması, bilimsel verilere açık erişim gerektirir. Çünkü birden fazla bilgi kaynağını bir araya getirmeden bir afet olayının nedenini ve etkisini tam olarak anlamak mümkün değildir. Günümüzde, izleme ekipmanından elde edilen veriler, temel haritalar, değerlendirme, sosyoekonomik istatistikler vb. gibi afetle ilgili büyük miktarda bilimsel veri mevcuttur. Bununla birlikte, genellikle coğrafi olarak dağılmışlardır ve çeşitli devlet kurumlarına, araştırma merkezlerine, özel kuruluşlara ve bazen dünyanın her yerinden bireyler de dâhil olmak üzere çok çeşitli paydaşlara aittirler. Araştırmacılar tarafından çalışma yapabilmek için gerekli tüm ilgili 
verilere ulaşmanın imkânsız olmasa da zor olduğu belirtilmektedir. İster çeşitli etkilerin nedensel ilişkisini analiz etmek, isterse de gelecekteki afet olaylarının etkisini tahmin etmek için modelleme yapmak olsun, afet riski araştırmalarındaki temel zorluk, birden çok veri kaynağından yararlanmak ve temelde yatan ilişkileri sentezlemek ve keşfetmektir (Li vd., 2018:46; Guha-Sapir vd., 2004:18). Bir diğer zorluk ise, veri tabanı platformlarının doğal kaynaklı afet kavramını tanımlamada ve giriş kriterlerini belirlemede sahip oldukları farklılıklardır (Below vd., 2009:10).

Afet bilgi sistemleri çok fazla afet ve acil durumların yaşandığı ülkemiz açısından da oldukça önemlidir. Afet ve acil durumlarla ilgili bilgilerin doğruluğu, erişilebilirliği ve bilgi kaynaklarının çeşitliliği karar vericilerin ve afet ile ilgili çalışma yapan araştırmacıların gelecek planlamasını daha güvenli ve daha uygulanabilir zeminde yapmalarını sağlayacaktır. Afetle ilgili bilgilerin tek bir merkezden paylaşılması ile, bilgi kirliliğinin önüne geçerek verilerin güvenilir ve hızlı bir şekilde hedefine ulaşması sağlanacaktır. Verilerin birleştirilmesi, kaynaştırılması ve tamamlanması için açık ve temiz standartlara, metodolojilere ve tanımlara ihtiyaç vardır. (Ural vd., 2014:45; Guha-Sapir vd., 2004:15). Diğer bir ifade ile küresel ölçekte belirlenmiş kriterlerle ortak bir afet veri tabanı oluşturmak ve erişime açık hale getirmek, ortaya çıkabilecek tüm olumsuzların ortadan kalkmasina ya da azalmasina yardımcı olacaktır.

Ülkemizde farklı kurum ve kuruluşlar tarafından sorumlu oldukları afet türü ile ilgili istatistikî bilgiler kayıt altına alınmaktadır. Buradaki en önemli zorluk, her bir afet için aynı format ve uzunlukta verinin olmamasıdır. Farklı kurum ve kuruluşlar tarafindan tutulan verilerin ve bilgilerin ortak bir platformda bir araya getirilmesi gerekmektedir. $\mathrm{Bu}$ işlem yapılırken mümkün olduğunca tekrara düşülmemesi ve eksikliklerinin giderilmesine dikkat edilmesi gerekmektedir (Özmen ve Özden, 2013:21). Ülkemizde afet yönetimi konusunda yetkin olan kurum afet yönetiminde çok başlılığı ortadan kaldırmak için kurulan AFAD'dır. Ancak AFAD'ın bu konuda rol ve sorumluluklarının çekingen olması ile diğer kurumlarla olan ilişkilerinin oldukça zayıf olması afet yönetimi açısından sorunlar ortaya çıkarmaktadır (Karaaslan, 2015:1).

Söz konusu konu ile ilgili problemlerin ortadan kaldırılması için ülkemizdeki doğal afetlerin geniş kapsamlı değerlendirilebilmesi, geçmiş afetlerden dersler çıkarılabilmesi amacıyla "Türkiye Ulusal Afet Arşiv Sistemi (TUAAS)" kurulmuştur. 2010 yılı başında kullanıcılara açılan sistemle Türkiye'de bugüne kadar yaşanan her türlü afet bilgileri bilgisayar ortamında kullanıcılara sunulmuştur. 2012 yılında ise AFAD tarafindan Ulusal Deprem Araştırma Programı (UDAP) kapsamında Orta Doğu Teknik Üniversitesi (ODTÜ) tarafından önerilen "Türkiye Afet Bilgi Bankası (TABB)" projesi kabul edilmiştir. TABB, Türkiye Afet Arşiv Sisteminin (TUAAS) devamı niteliğinde olduğu söylenebilir (Ural vd., 2014:46). Ülkemiz adına gerçekleştirilen bu program ve proje, afetlere dair güvenilir bilgiye tek elden erişim imkânı sağlamak için oldukça önemlidir.

\section{TÜRKIYYE AFET BILGİ BANKASI (TABB)}

Bilgi bankasının kurulması ile karar vericilere, uygulayıcılara ve araştırmacılara çalışmalarında yardımcı olmak, toplumun karşı karşıya olduğu risklerin farkında olmasını ve toplum tarafından bu risklerin daha iyi anlaşılmasını sağlamak amaçlanmıştır. Bunun yanında afet risk yönetimi kapsamında araştırmacıların ve karar vericilerin ihtiyaç duyduğu meydana gelmiş afetlerin bilgilerinin elektronik ortamda hizmete sunulması sağlanmıştır (URL-1).

Ülkemizde sık sık afetler meydana gelmekte ve yıkıcı etkiye neden olmaktadır. Günümüzde risk odaklı afet yönetimi anlayışı önem kazanmakta olup zarar azaltma ve hazırlık aşaması kapsamında yapılan çalışmalarda hem araştırmacıların hem de karar vericilerin meydana gelmiş afetlerin bilgilerine kolay ulaşabilmeleri büyük önem arz etmektedir. Dolayısıyla karar vericiler, yöneticiler ve araştırmacılar stratejilerini ve politikalarını bu bilgi birikimini dikkate alarak oluştursunlar. Bilgi bankası, gelecek nesillere bu bilgi birikiminin taşınmasında önemli bir rol oynamaktadır. Aynı zamanda araştırmacılar ve karar vericiler bilgi bankası sayesinde analizler yapabilme ve bu analizler doğrultusunda strateji ve politika belirleme imkânına sahip olmaktadır. Bu kapsamda afet yönetimi ile ilgili yapılan çalışmalara girdi teşkil edecek hem güvenli verilere sayısal ortamda ulaşılmasına hem de bunun tek elden gerçekleşmesine olanak sağlayan TABB, AFAD tarafindan kurulmuştur (URL-1).

TABB, ODTÜ tarafindan yürütülmüş bir proje ürünüdür. TABB projesi ile ODTÜ Afet Yönetim Merkezi tarafından Türkiye Afet ve Acil Durum Yönetimi Başkanlığı (AFAD) için doğal afetlerin mevcut materyal ve kaynaklarını tek bir portalda toplanması hedeflenmiştir (Başbuğ vd., 2015:441). TABB ile ülkemizde meydana gelmiş afet ve acil durumların gün yüzüne çıkarılması ve meydana gelmekte olan afetlerin gelecekteki bilimsel çalışmalara 1şık tutması amaçlanmıştır (URL-2). Türkiye Afet Bilgi Bankası tasarlanırken Desinvanter (Latin Amerika'da afetlerin önlenmesi için Sosyal Çalışma Ă̆l -LA Red-veri tabanı), EM-DAT (Afetlerin Kökeni 
Üzerine Araștırma Merkezi -CRED- veri tabanı) gibi mevcut uluslararası afet bilgi bankaları göz önünde bulundurulmuştur (Ural vd., 2014:45).

TABB, Mayıs 2015'te AFAD web sayfasında yayına girmiştir (URL-5). TABB, hem İngilizce hem de Türkçe olarak sunulan iki dilli bir sistemdir. TABB'da afet dokümantasyonu ve veri analizi modülü aynı platform üzerinde yer almaktadır (Başbuğ vd., 2015:441). Doküman kısmı ile çeşitli kurum ve kuruluşlar ile kütüphanelerde yer alan ve aynı zamanda elektronik ortamda bulunan afet ile ilgili bilgi kaynaklarına ulaşma imkânı sağlanmıştır (URL-2). Dokümantasyon bölümü elektronik materyal olarak engelliler için elektronik kitaplar, kurumsal raporlar, tezler, makaleler, resimler, videolar, sunumlar, sesli materyaller, süreli yayınlar ve materyaller yer alırken elektronik olmayan materyal olarak ise söz konusu materyallerin konum bilgileri (fiziksel veya internet adresi) yer almaktadır. Analiz kısmı ise istatistiksel verilere ihtiyaç duyan araştırmacılar için oluşturulmuştur. Analiz kısmı ile arşivde bulunan verileri değerlendirerek grafikler, haritalar ve raporlar gibi bazı istatistiksel modüller oluşturulabilir ve grafik çizdirme işlemleri de yapılabilir. Araştırmacılar veri tabanından seçebilecekleri spesifik verilerin temel istatistiksel analizini üretebilir ve ayrıca daha fazla analiz yapmak için istenen verilerin "xls" formatını indirebilirler (Başbuğ vd., 2015:441). Araştırmacılar TABB aracılığıyla istatistiksel verilere analiz kısmından, bilgi kaynaklarına ise doküman kısmından çok rahat bir şekilde ulaşabilmektedirler (URL-2).

\section{AFETLERIN EPIDEMIYOLOJISİ ARAŞTIRMA MERKEZI (CRED-THE CENTRE FOR RESEARCH OF THE EPIDEMIOLOGY OF DISASTERS)}

Afetlerin Epidemiyoloji Araştırma Merkezi (CRED) Belçika Kanunu uyarınca uluslararası statüsüne sahip, kâr amac1 gütmeyen bir kurum olarak 1973 yılında kurulmuştur. Brüksel'deki Louvain Katolik Üniversitesi (LKÜ) Halk Sağlığı Okulu içinde yer almaktadır (URL-3). Merkezin Brüksel de olması sayesinde değişik Avrupa Komisyonları programları ve organizasyonlarıyla birlikte çalışma olanağına sahiptir. Geniş çalışma alanının içinde veritabanı yönetimi de bulunmaktadır. Merkezin web sayfasında EM-DAT (Afet Acil Durum Veri Tabanı -Emergency Disaster Database), EM-BİB Dokümantasyon Merkezi, Bibliyografik Veri Tabanı ve CE-DAT Silahlı Çatışmaların İnsani Etkileri Veri Tabanı bölümleri yer almaktadır (Hamzaçebi vd., 2007).

CRED, uzun bir standartlaştırılmış veri derleme, doğrulama ve analiz geçmişine sahiptir. Web sitesi (http://www.emdat.be/) aracilığıyla verilerine ücretsiz ve açık erişim sağlar. CRED'in temel veri ürünlerinden biri, uluslararası afet veri tabanı olan Acil Durum Veri Tabanı'dır (URL-3). EM-DAT, Dünya Sağlık Örgütü (WHO) ve Belçika Hükümeti'nin desteği ile 1988'de oluşturulmuştur. Veri tabanının temel amacı, ulusal ve küresel düzeyde insani yardım faaliyetlerinin amaçlarına hizmet etmektir.

EM-DAT, ekonomik hasar tahminleri ve afete özel uluslararası yardım katkılarının yanı sıra ölen, yaralanan veya etkilenen kişi sayısı gibi afetlerin insanoğlu üzerindeki etkisi hakkında bilgi sağlamaktadır. EM-DAT, doğal kaynaklı afetler ve teknolojik afetler de dâhil olmak üzere 1900'den günümüze kadar 15.700'den fazla felaketin oluşumu ve etkileri hakkında temel verileri içermektedir (Climate-Adapt, 2021). Kayıt bilgileri 1900'lere kadar uzanır ve her yıl yaklaşık 300 olay eklenir (Wirtz vd., 2014:138).

EM-DAT veri tabanında rakamlar dâhili olarak günlük güncellenmektedir. Ancak kamuya açık bilgiler, tüm veriler doğrulandıktan ve farklı kaynaklar kullanılarak çapraz kontrol edildikten sonra her 3 ayda bir düzenli olarak güncellenmektedir (URL-3).

\section{VERİ TABANLARININ TEMEL ÖZELLIKLER BAKIMINDAN KARŞILAŞTIRILMASI}

Çalışmanın bu kısmında her iki veri tabanı temel özellikler bakımdan karşılaştırılarak incelenmiştir. Öncelikle her iki veri tabanı incelendikten sonra temel özelliklerini gösteren alt başlıklar oluşturulmuştur. Her iki veri tabanı kuruluş, kapsam, metodoloji, afet türleri, dâhil edilme kriterleri, veri başlıkları, veri kaynakları, erişim, glide numarası, veri arama yöntemi, grafik oluşturma ve sözlük gibi alt başlıklar kapsamında karşılaştırılarak, farklılıklar ve benzerlikler saptanmaya çalışılmıştır. Bu benzerlik ve farkılılıkların saptnamasında bir bütünlük sağlamak amaciyla Tablo 2 oluşturulmuştur. 
Tablo 2. EM-DAT ve TABB Veri tabanlarının Temel Özellikleri Açısından Karşılaştırılması

\begin{tabular}{|c|c|c|}
\hline Temel Özellikler & EM-DAT & TABB \\
\hline Kuruluş & 1988 & 2015 \\
\hline Kapsam & \begin{tabular}{|l|} 
- 1900 - Günümüz \\
• 200'den fazla ülke \\
\end{tabular} & $\begin{array}{l}\text { - } 1923-\text {-Günümüz } \\
\text { • } 81 \text { il }\end{array}$ \\
\hline Metodoloji & • Ülke düzeyinde girişler (Kıta, Bölge, Ülke, Yer, Orijin) & $\begin{array}{l}\text { - Olay girişleri için hiyerarşik metodoloji: il, ilçe, } \\
\text { mahalle, kasaba ve köy düzeyi girişler. }\end{array}$ \\
\hline Afet Türleri & $\begin{array}{l}\text { - Afetler sınıflandırılmıştır. } \\
\text { - Doğal afetler: Jeofiziksel, meteorolojik, hidrolojik, klimatolojik } \\
\text { biyolojik } \\
\text { - Teknolojik afetler: Endüstriyel kazalar, ulaşım kazaları ve çeşitli } \\
\text { kazalar } \\
\text { - Karmaşık felaketler }\end{array}$ & $\begin{array}{l}\text { - Afetlerin sınıflandırması yapılmamıştır. } \\
\text { - Doğal afetler: Jeofiziksel, meteorolojik, hidrolojik, } \\
\text { klimatolojik ve biyolojik } \\
\text { - Teknolojik afetler: Endüstriyel kazalar, ulaşım } \\
\text { kazaları ve çeşitli kazalar } \\
\text { - Terörizm olayları, } \\
\text { - Çevresel Kirlenmeler } \\
\text { - Kaçırma olayları } \\
\text { - Yapısal Çökme }\end{array}$ \\
\hline Dâhil Edilme Kriterleri & $\begin{array}{l}\text { - } 10 \text { veya daha fazla can kaybı } \\
\text { - } 100 \text { veya daha fazla kişinin etkilenmesi } \\
\text { - Devlet tarafindan olağanüstü hal ilanı } \\
\text { - Uluslararası destek çağrısı } \\
\end{array}$ & - Herhangi bir kriter bulunmamaktadır. \\
\hline Veri Başlıkları & $\begin{array}{l}\text { - Glide Numarası } \\
\text { - Afet Grubu (Afet Alt Grubu, Ana Adet Türü, Afet Alt Türü) } \\
\text { - Afetin Meydana Geldiği Yer (Kita, Bölge, Ülke, Yer) } \\
\text { - Afet Başlangıç ve Bitiş Tarihi ile Yerel Saat } \\
\text { - İnsan ölümleri: ölümler + kayıp } \\
\text { - Toplam etkilenen: yaralı, evsiz ve diğer etkilenmiş } \\
\text { - Hasarlar: toplam ekonomik hasarlar (USD), sigortalı kayıplar, } \\
\text { yeniden inşa maliyetleri } \\
\text { - Giriş Kriterleri } \\
\text { - Enlem/Boylam } \\
\text { - Olay Adı } \\
\text { - Menşei } \\
\text { - Afetin Büyüklük Ölçeği ve Değeri } \\
\text { - Afete Yardım Desteği } \\
\text { - Ülkenin Uluslararası Alandan Yardım Talebi ve Zamanı } \\
\text { - Olağanüstü Hal İlanı }\end{array}$ & $\begin{array}{l}\text { - Glide numarası } \\
\text { - Afet Türü } \\
\text { - Afetin meydana geldiği yer (İl, İlçe, Köy, Mahalle, } \\
\text { Belde) } \\
\text { - Afetin Başlangıç Tarihi } \\
\text { - Etkilediği Alan } \\
\text { - Ölü Sayısı (Çocuk, Yetişkin, Kadın ve Erkek) ve } \\
\text { Kayıp İnsan Sayısı } \\
\text { - Yaralı Sayısı (Çocuk, Yetişkin, Kadın ve Erkek) } \\
\text { - Etkilenenler, Yer Değiştirenler, Tahliye Edilenler } \\
\text { - Toplam Hasarlı Bina Sayısı ve Toplam Yıkık Bina } \\
\text { Sayısı (Konut, Kamu ve İşyeri (Hasarsı, Hafif, } \\
\text { Orta, Ağır ve Yıkık) } \\
\text { - Toplam Maliyet (TL) (USD) } \\
\text { - Zarar Gören Tarım Alanı } \\
\text { - Büyükbaş Hayvan Kaybı }\end{array}$ \\
\hline Veri Kaynakları & $\begin{array}{l}\text { - BM ve ABD hükümetinin ajansları } \\
\text { - Ulusal hükümetler } \\
\text { - Araştırma merkezleri } \\
\text { - Hükümetler arası kuruluşlar } \\
\text { - Lloyd'un reasürans kaynakları } \\
\text { - Basın }\end{array}$ & $\begin{array}{l}\text { - } 81 \text { İl Afet ve Acil Müdürlüğü } \\
\text { - Anadolu Ajansı }\end{array}$ \\
\hline Veri Erişimi & $\begin{array}{l}\text { - Üyelik sonrasında verilere erişilebilir. } \\
\text { - İndirme işlemi yapılabilir (.xls - İstenilen sayıda afet türü). }\end{array}$ & $\begin{array}{l}\text { - Veri erişimi için üyelik gerekmez. } \\
\text { - İndirme işlemi yapılabilir (.xls, .doc, .pdf - Her bir } \\
\text { afet ve acil durum türü için tek tek). }\end{array}$ \\
\hline Glide Numarası & - Var & - Var \\
\hline Veri Arama Yöntemi & - Basit Veri Araması & - Kapsamlı Veri Araması \\
\hline $\begin{array}{l}\text { Grafik ve Harita } \\
\text { Oluşturma }\end{array}$ & - Evet & - Evet \\
\hline Sözlük & - Var & - Yok \\
\hline
\end{tabular}

Kaynak: URL-3 ve URL-4

- Kuruluş: EM-DAT veri tabanı 1988 yılında kurulmuştur TABB veri tabanı ise AFAD internet sayfasında 2015 yılı mayıs ayı itibari ile yayına başlamıştır (URL-3 ve URL-4).

- Kapsam: EM-DAT veri tabanı uluslararası düzeyde 200'den fazla ülkede 1900 yılından günümüze kadar meydana gelmiş ve gelmekte olan afetlerin bilgilerini kaydetmektedir. TABB tarafindan ise 1923'ten günümüze kadar ülkemizin 81 ilinde meydana gelmiş ve gelmekte olan afetlerin bilgilerinin kaydı tutulmaktadır (URL-3 ve URL-5).

- Metodoloji: EM-DAT veri tabanında afetlerin meydana geldiği kıta, ülke, bölge ve yer bilgileri bulunmaktadır. Yer bilgisi şehir, köy, bölüm, il, eyalet veya bölgenin adıdır. Yer bilgisi, afet oluşumunun ve etkisinin daha sonra bölge, ilçe veya başka herhangi bir alt ulusal idari sınır tarafından analiz edilmesine 
olanak sağlamaktadır. TABB veri tabanında ise il, ilçe, mahalle, kasaba ve köy düzeyinde girişler yapilmaktadir (URL-3 ve URL-4).

- Afet Türleri: Her iki veri tabanı da, hem doğal hem de insan kaynaklı afetler bu tür afet olaylarının çeşitli sosyo-ekonomik etkilerinin analizi hakkında bir dizi bilgi sağlamaktadır. EM-DAT veri tabanında afet türlerinin sınıflandırması yapılmıştır. Bu sınıflandırma Tablo 3'te gösterilmiştir. Buna göre afetler doğal ve teknolojik afetler olmak üzere iki başlıkta sınıflandırılmıştır. Bu sınıflandırmaya göre afet grupları afet alt grubuna, afet alt grubu da ana afet türüne bağlanmaktadır. Doğal afetler grubu, afet alt grubu kapsamında 6 gruba ayrılmıştır. Bunlar jeofiziksel, meteorolojik, hidrolojik, klimatolojik, biyolojik ve dünya dışı afetlerdir. Teknolojik afetler grubu ise, afet alt grubu kapsamında endüstriyel kazalar, ulaşım kazaları ve çeşitli kazalar olmak üzere toplamda üç gruba ayrılmıştır.

İki veya daha fazla afetin meydana gelmesi ana afet türü ile ilişkili olabilmektedir (birincil bir olayın sonucu olarak bir afet meydana gelebilir). Örneğin, bir siklon, sel veya heyelan oluşturabilir veya bir deprem, bir gaz hattının kopmasına ve çevreyle ilgili bir felakete neden olabilir (URL-3).

TABB sistemine bakıldığında EM-DAT veri tabanında olduğu gibi afet türleri ile ilgili bir sınıflandırma bulunmamaktadır. TABB'da EM-DAT'a göre daha fazla afet ve acil durum tipi olayların kayıt altına alındığ 1 görülmektedir. EM-DAT veri tabanından farklı olarak terörizm olayları, çevresel kirlenmeler, ulaşım araçlarının kaçırılma olayları, yapısal çökmeler, kaybolma, erozyon, siber saldırılar, kitlesel ayaklanmalar göçme olayları (Mağara-karstik boşluk çökmesi, obruk-dolin çökmesi ve zemin yenilmesi çökmesi) gibi afet ve acil durum türlerine de yer verilmiştir. TABB veri tabanı tarafından farklı afet ve acil durum türlerinin de kayıt altına alındığı görülmektedir (URL-3 ve URL-4).

Tablo 3. EM-DAT Veri Tabanında Kullanılan Afet Sınıflandırması

\begin{tabular}{|c|c|c|c|c|c|c|}
\hline $\begin{array}{l}\text { Afet } \\
\text { Grubu }\end{array}$ & $\begin{array}{l}\text { Afet Alt } \\
\text { Grubu }\end{array}$ & Ana Afet Türü & Afet Alt Türü & Afet Grubu & Afet Alt Grubu & Ana Afet Türü \\
\hline \multirow{36}{*}{$\begin{array}{l}\text { Doğal } \\
\text { Afetler }\end{array}$} & \multirow{8}{*}{ Jeofiziksel } & \multirow{2}{*}{ Deprem } & Yer Hareketi & \multirow{16}{*}{$\begin{array}{l}\text { Teknolojik } \\
\text { Afetler }\end{array}$} & \multirow{8}{*}{$\begin{array}{l}\text { Endüstriyel } \\
\text { Kazalar }\end{array}$} & Kimyasal dökülme \\
\hline & & & Tsunami & & & Çökme \\
\hline & & \multirow{2}{*}{ Kütle Hareketi (Kuru) } & Kaya Düşmesi & & & Patlama \\
\hline & & & Heyelan & & & Yangın \\
\hline & & \multirow{4}{*}{ Volkanik Faaliyet } & Kül yağışı & & & Gaz Sizıntıs1 \\
\hline & & & Lahar & & & Zehirlenme \\
\hline & & & Piroklastik akış & & & Radyayon \\
\hline & & & Lav akış1 & & & Diğer \\
\hline & & & Kıyı seli & & & Hava \\
\hline & & & Nehir seli & & & Kara \\
\hline & & Sel & Su baskını & & Ulaşım Kazaları & Demiryolu \\
\hline & Hidrolojik & & Buz reçeli seli & & & Deniz \\
\hline & & Heyelan & Çı̆̆ (kar, enkaz, çamur akışı, kaya düş.) & & & Çökme \\
\hline & & & Haydut dalga & & & Patlama \\
\hline & & Dalga Hareketi & Duran Dalga & & Çeşıtlı kazalar & Yangin \\
\hline & & Kuraklık & & & & Diğer \\
\hline & Klimatolojik & Buzul Gölü Patlaması & & & & \\
\hline & & Orman yangını & Kara yangını: Fırça, çalı, Mera & & & \\
\hline & & & Viral hastalık & & & \\
\hline & & & Bakteriyel Hastalık & & & \\
\hline & & Epidemi & Paraziter Hastalık & & & \\
\hline & Biyolojik & & Mantar Hastalığ1 & & & \\
\hline & & & Prion Hastalığ & & & \\
\hline & & Böcek İstilas1 & Çekirge & & & \\
\hline & & Hayvan Kazası & & & & \\
\hline & & Darbe & Hava patlamas1 & & & \\
\hline & & & Enerjik parçacıklar & & & \\
\hline & Dunya Diş1 & Uzay Havası & Jeomanyetik firtına & & & \\
\hline & & & Şok dalgas1 & & & \\
\hline & & & Tropikal firtına & & & \\
\hline & & Firtına & Tropik dışı firtına & & & \\
\hline & & & Konvektif firtına & & & \\
\hline & Meteorolojik & & Soğuk dalga & & & \\
\hline & & Aşırı Sıcaklık & Sicak hava dalgası & & & \\
\hline & & & Şiddetli kış koşulları & & & \\
\hline & & Sis & & & & \\
\hline
\end{tabular}

Kaynak: Yazarlar tarafından 19.02.2021 tarihinde EM-DAT veri tabanından elde edilerek hazırlanmıştır (URL-3) 
- Dâhil Edilme Kriterleri: Araştırma esnasında TABB veri tabanı tarafından bir afet kayıt altına alınırken dikkate alınan herhangi bir kriter varlığına rastlanılmamıştır. Ancak TABB veri tabanının başlangıcı niteliğinde olan TUAAS veri tabanında ise dahil edilme kriterleri bulunmaktaydı. Bunlar;

En az 10 ölünün olması durumunda

$>$ En az 50 yaralı olması durumunda

$>$ Afetten etkilenen en az 100 kişi olması durumunda

$>$ Genel hayatın olumsuz etkilenmesi durumunda

$>$ Acil yardım talebinde bulunulması durumunda

Bu bahsedilen kriterlerden en az biri gerçekleştiğinde afet olayı TUAAS veri tabanı tarafından kayıt altına alınmaktaydı (Gökçe vd., 2008;7). Ancak TABB veri tabanının dahil edilme kriteri olup olmadığı konusunda herhangi bir bilgiye ulaşılamamıştır. Fakat Tablo 4'e bakıldığında TABB veri tabanı tarafından kaydedilen depremlerin hasar göstergelerinin düşük olmasına rağmen kayıt altına alınması böyle bir kriterin olmadığını düşündürmektedir. EM-DAT veri tabanı incelendiğinde ise bir afet olayının kayıt altına alınabilmesi aşağıda verilen kriterlerden en az birinin ortaya çıkması gerekmektedir. Bir afetin EM-DAT tarafından kayıt altına alınabilmesi için gerçekleşmesi gereken kriterler (durumlar) aşağıda verilmiştir (URL-3).

$>$ On (10) veya daha fazla kişi hayatını kaybettiğinde,

> Yüz (100) veya daha fazla kişi etkilendiğinde,

$>$ Olağanüstü hal ilan edildiğinde,

Uluslararası yardım çağrısı yapıldığında,

Sonuç olarak bir afetin EM-DAT veri tabanına girilebilmesi için söz konusu kriterler nedeniyle zarar ve hasarının büyük olması gerektiği ortaya çıkmaktadır. Orta ve küçük zarar ve hasara neden olan afetler ise EM-DAT tarafindan kayıt altına alınmamaktadır (URL-3).

- Veri Başıkları: Veri başlıkları ile ilgili olarak bu kısımda her iki veri tabanından 2010 ile 2020 yıllarında meydana gelen depremlerin bilgileri “".xls" formatında indirilerek karşılaştırma yapılmıştır. Glide numarası, ana afet türü, afetin meydana geldiği yer, afetin başlangıç tarihi, ölü sayısı, yaralı sayışı, kayıp sayısı, toplam maliyet ve etkilenen kişi sayısı gibi veri başlıkları içeriklerinde çok küçük farklılıklar olsa da her iki veri tabanında bulunmaktadır (URL-3 ve URL-4). EM-DAT veri tabanında ölü sayıs1 denildiğinde olay sonrası hayatını kaybedenlerin sayısı akla gelirken toplam ölü sayısı denildiğinde ise olay nedeniyle hayatını kaybedenlerin sayısına ilave olarak afet nedeniyle nerede olduğu bilinmeyen ve resmi rakamlara göre ölü olduğu tahmin edilen kişilerde bu grup içerisinde değerlendirilmektedir. EMDAT veri tabanında kayıp insan sayısı, ölü sayısının içerisinde verilmesine karşın TABB veri tabanında ise ölü sayısı ve kayıp insan sayısı ayrı ayrı verildiği görülmektedir. Ancak bu durumda kayıp olan insanların ölü olarak değerlendirilip değerlendirilmeyeceği ile ilgili bir karışıklık ortaya çıkmaktadır (URL-3 ve URL-4). Yaralı sayısı denildiğinde ise bir afet nedeniyle fiziksel yaralanma, travma veya acil tıbbi yardım gerektiren bir hastalıktan muzdarip insanlar ifade edilmektedir. EM-DAT veri tabanına göre yaralılar her zaman toplam etkilenenlerin bir parçasıdır. Toplam etkilenen denildiğinde ise yaralılar, evsizler ve etkilenmiş kişiler ifade edilmektedir. Ancak TABB veri tabanında yaralıların etkilenenlerin içeresinde değerlendirilip değerlendirilmediği ile ilgili bir bilgiye rastlanılmamıştır. Aynı zamanda TABB veri tabanı tarafından etkilenenler, yer değiştirenler ve tahliye edilenler şeklinde ayrı ayrı veri başlığı bulunmaktadır. Bu üç veri başlığı ile ifade edilmek istenenin tam olarak ne olduğu net olmamakla birlikte araştırmacılar üzerinde kafa karışıklığına neden olabileceği düşünülmektedir (URL-3 ve URL-4). EMDAT bünyesinde bulunup da TABB bünyesinde bulunmayan veri türleri şunlardır (URL-3ve URL-4);

$\checkmark$ "Olay Adı", olay adı olarak ifade edilmek istenen şey afet ile ilgili tanımlanmasına izin veren herhangi bir özellikten yola çıkılarak verilen isimdir (Örnek: Fırtınanın adı için "Mitch", hava kazasındaki uçak türü için "Boeing 707", salgın için "Kolera", yanardağın adı için "Etna", vb.).

$\checkmark$ "Afetin Bittiği Tarih", veri başlığı tüm ani etkili afetler için tanımlanmıştır. Kesin bir bitiş tarihi olmayan daha uzun bir süre boyunca sona eren afet durumları (Örnek: kuraklık) için, "gün" alanı boş bırakılmaktadır.

$\checkmark$ "Yerel Saat", veri başlığı ile afetin meydana geldiği yerdeki saat ifade edilmektedir (depremler ve 

yanardağlar gibi hızlı gelişen afetler için verilmiştir).

$\checkmark$ "Afetin Menşei”, veri başlığı ile afetin tetikleyici kaynağı ifade edilmektedir (Örnek: Sel için şiddetli yağışlar, orman yangını için kuraklık).

$\checkmark$ “1. ve 2. İlişkili Afetler", veri başlı̆g ile birincil afet sonrasında ikincil ve/veya ilişkili etkileri veya sonuçlarının oluşması belirtilmektedir (Örnek: Sel için heyelan, deprem sonrası patlama, vb.).

$\checkmark$ "Afetin Büyüklük Ölçeği ve Değeri”, afetin büyüklüğü ve değeri ifade edilirken kullanılan birimler afetin türüne göre değişiklik göstermektedir (Deprem: Richter Ölçeği, Sel: $\mathrm{Km}^{2}$-kaplı alan-, Aşırı Sicaklık: ${ }^{\circ} \mathrm{C}$-minimum veya maksimum değer).

$\checkmark$ "Afet Yardım Desteği", afete yanıt olarak ülkeye verilen acil yardım faaliyetleri için katkının toplam tutarını ifade etmektedir.

$\checkmark$ "Yabancı Afet Yardım Ofisi'nin (OFDA) Müdahalesi", veri başlığı ile Yabancı Afet Yardım Ofisi'nin (OFDA) afete müdahale edip etmediği ifade edilmektedir.

$\checkmark$ "Ülkenin Uluslararası Alandan Yardım Talebi ve Zamanı", veri başlığı ile etkilenen ülkelerden herhangi bir uluslararası yardım talebinin olup olmadığı ve ne zaman talep edildiği belirtilmektedir.

$\checkmark$ “Olağanüstü Hal İlanı”, veri başlığı ile ülkeler de olağanüstü hal ilan edilip edilmediği ve edildiyse ne zaman ilan edildiği belirtilmektedir.

$\checkmark$ "Enlem" ve "Boylam", afetin meydana geldiği yerin enlem ve boylam değerlerini ifade etmektedir.

$\checkmark$ "Yeniden İnşa Maliyeti”, veri başlı̆̆ı ile kayıp varlıkların yenilenmesi için harcanan maliyet ifade edilmektedir. Yeniden inşa maliyetleri, malların mevcut inşaat veya satın alma maliyetlerinin yanı sıra gelecekteki afetlerden kaynaklanan hasarı azaltmak için ek önleme ve hafifletme önlemleri maliyetlerini de hesaba katmaları gerektiğinden toplam maliyetten farklıdır.

$\checkmark$ "Sigortalı Kayıplar", veri başıı̆ı ile sigorta şirketleri tarafından karşılanan ekonomik zararlar ifade edilmektedir.

$\checkmark$ "Giriş Kriteri", veri başlığı ile afetin hangi kriterden dolayı veri tabanına girildiğini göstermektedir.

TABB veri tabanı bünyesinde bulunup da EM-DAT veri tabanı bünyesinde bulunmayan veri başlıklarına bakılacak olursa zarar gören tarım alanı, büyükbaş hayvan kaybı, ölü ve yaralı sayısı (çocuk, yaşll, kadın, yetişkin, erkek), hasarsız, hafif, orta, ağır ve yıkık bina sayısı (kamu, işyeri ve konut) şeklindedir. TABB veri tabanı afet veri setleri bu haliyle bir afet olayı hakkında araştırmacıların ve karar vericilerin detaylı analiz yapabilmesine imkân sunmaktadır. Ancak TABB veri tabanından indirilen ".xls" dosyası incelendiğinde ölüm ve yapılarda hasar oluşmasına rağmen bahse konu olan veri başlıklarına herhangi bir değer girilmemiş olduğu görülmektedir (URL-3 ve URL-4).

TABB bünyesinde de "afetin etkilediği alan" bölümü bulunurken EM-DAT veri tabanında ise etkilediği alanla ilgili bir veri başlığı bulunmamaktadır. Sadece afetin büyüklüğü ifade edilirken ölçü birimi ve değeri başlığı yer almaktadır (örneğin, sel için $1200 \mathrm{~km}^{2}$ ). TABB veri tabanında etkilenen alan kısmı incelendiğinde daha çok yer isimleri verilerek etkilenen alan belirtilmiştir. Herhangi bir sayısal bilgi verilmemiştir. $\mathrm{Bu}$ da analizlerin yapılmasında bu veri başlığının kullanılmasını zorlaştırmaktadır. TABB bünyesinde meydana gelen afet sonrası oluşan zararların ve hasarların toplam maliyetine yer verildiği görülmektedir. EM-DAT veri tabanında ise tahmini toplam hasar, sigorta kapsamındaki ve yeniden inşa kapsamındaki maliyetlere de yer verilmiştir. Bu veri başlıkları araştırmalarda kullanılacak önemli veriler olduğu düşünülmektedir (URL-3 ve URL-4).

- Veri kaynakları; EM-DAT veri tabanı, BM, hükümet ve sivil toplum kuruluşları, sigorta şirketleri, araştırma enstitüleri ve basın kuruluşları dâhil olmak üzere çeşitli kaynaklardan derlenmiştir. Çelişkili bilgi ve rakamlar olabileceğinden, CRED bu kaynakları güvenilir ve eksiksiz veri sağlama yeteneklerine göre derecelendirmek için bir yöntem oluşturmuştur. Bir afet EM-DAT'a en az iki kaynak tarafindan afetin meydana geldiği bildirildiğinde kayıt işlemi yapılmaktadır. TABB veri tabanına veriler, Anadolu Ajansından ve 81 il AFAD taşra teşkilatlarından sağlanmaktadır. Her il AFAD Müdürlüğü, kendi verisini değerlendirip AFAD'a göndermektedir. Gönderilen veriler AFAD sorumlu personelleri tarafından son kez gözden geçirilerek TABB sistemine dâhil edilmektedir (URL-3 ve URL-4). 
- Erişim Durumu, EM-DAT veri tabanında üyelik sonrası veri erişimi gerçekleştirilebilmektedir. Veriler istenilen sayıda afet türü seçimi yapılarak ".xls" formatında indirilebilmektedir. TABB veri tabanında ise sisteme üye olmadan verilere ulaşmak mümkündür. Veriler her bir afet ve acil durum türü için tek tek seçim yapıldıktan sonra .xls, .doc ve .pdf formatlarında indirilebilmektedir (URL-3 ve URL-4).

- Global kimlik numarası, EM-DAT veri tabanında afetler kayıt altına alınırken glide numarası kullanılmaktadır. Çeşitli afet veri tabanları ve ReliefWeb gibi web sitelerindeki kayıtlar arasındaki bağlantıları kolaylaştırmayı amaçlayan, afetler için küresel olarak kullanılan benzersiz kimlik kodudur. Global kimlik numarasının başında ilk 2 hanede afetin türü, kısaltmasıyla belirtilmektedir. Devamında ki 4 hane ise afetin meydana geldiği yılı, sonraki 6 hane ise sira numarasını, son 3 hane ise afetin meydana geldiği ülkenin ISO kodunu göstermektedir. (Örnek: EQ- 2020-000142- TUR). TABB veri tabanında ise EM-DAT'ta olduğu gibi glide numarası kullanıldığ 1 görülmektedir. TABB veri tabanında kullanılan glide numarasının değişmekle birlikte genellikle 12 haneli olduğu görülmektedir. Ancak kimlik kodundaki rakamların veya harflerin neyi ifade ettiği bilgisine ulaşılamamıştır (URL-3 ve URL-4).

- Veri Arama Yöntemi, Sözlük ve Grafik ve Harita Oluşturma: EM-DAT veri tabanı ile arama yapılacak ülke, afet türü ve tarih yıl şeklinde seçilerek basit olarak veri arama yapılabilmektedir. TABB veri tabanında ise seçim tercihi daha fazla olduğu görülmektedir. Arama yapılacak yer, afet türü, tarih gün, ay ve yıl şeklinde ve diğer istenilen veri başlıkları seçilerek arama yapılabilmektedir. TABB veri tabanı ilgili rapor farklı formatlarda indirilirken EM-DAT veri tabanında ise sadece ".xls" formatında indirme işlemi yapılabilmektedir. EM-DAT veri tabanı tarafından uluslararası düzeyde grafik, ülkeler ve dünya çapında ise harita oluşturmak mümkündür. TABB veri tabanında ise ulusal düzeyde istenilen afet türü, tarih aralığı ve veri seti seçildikten sonra grafik ve harita oluşturmak mümkün olmaktadır. EM-DAT veri tabanının sayfasında açıklayıcı notlar kısmında "sınıflandırma", "sözlük" ve "yönergeler" kısmı bulunmaktadır. Sözlük kısmında, EM-DAT hasar gösterge türlerinin ve sınıflandırması yapılan afetlerin açıklamalarının yapıldığı toplamda 98 kelime bulunmaktadır. TABB veri tabanında sınıflandırma, sözlük ve yönerge kısmı bulunmamaktadır (URL-3 ve URL-4).

\section{AFET HASAR GÖSTERGELERİ}

Çalışmanın bu kısmında afetlerin neden olduğu zarar ve kayıplarla ilgili veriler karşılaştırılmıştır. Bu bakımdan daha önce de belirtildiği gibi karşılaştırma için örneklem olarak 81 il, afet türü olarak ise deprem olayı seçilmiştir. Türkiye'nin tüm illeri için 2010 ile 2020 yılları arasında meydana gelen deprem verileri hem EMDAT veri tabanından hem de TABB veri tabanından Microsoft Excel formatında indirilmiştir. TABB veri tabanı tarafından kaydedilen deprem olaylarının toplamda 308 adet olduğu görülmektedir. 308 adet deprem olayı incelenerek sadece ölüme veya yaralanmaya neden olan deprem olayları dikkate alınmıştır ve Tablo 4'te gösterilmiştir. Tablo 4'te gösterilmeyen 303 deprem olayında ise herhangi bir ölüm ve yaralanmanın yaşanmadığı tespit edilmiştir. Bu da TABB veri tabanı tarafından afet olayları kayıt altına alınırken hiçbir dahil edilme kriterin olmadığını göstermektedir. Çünkü 308 deprem olayından aşağıda Tablo 4'te gösterilen deprem olayları haricinde yaşanan depremlerde ölü sayısı ve yaralı sayısının sıfır olduğu görülmektedir. Etkilenen kişi sayısı kategorisine bakıldığında ise 305 deprem olayında yine sıfır olduğu görülmektedir. Buna rağmen TABB veri tabanı tarafından bu deprem olayları kayıt altına alınmışıtır. EM-DAT veri tabanı tarafından söz konusu yıllar arasında kayıt altına alınan deprem olayının 12 adet olduğu görülmektedir. Bu depremlerin hangi dahil edilme kriteri dikkate alınarak kayıt altına alındığı da ayrıca belirtilmiştir (URL-3 ve URL-4).

2010 ile 2020 yılları arasında meydana gelen depremlerin neden olduğu ölü sayısı ve yaralı sayısı verileri Tablo 4 'te verilmiştir. TABB veri tabanı tarafından kayıt altına alınan ancak can kaybına ve yaralanmaya neden olmayan depremler tabloda yer verilmemiştir. EM-DAT tarafından kayıt altına alınan 12 deprem olayının tümü tabloda yer verilmiştir. 2010 ile 2020 yılları arasında EM-DAT veri tabanına göre toplamda 8 ilde, TABB veri tabanına göre ise toplamda 5 ilde can kaybına ve yaralanmaya sebep olan depremler meydana geldiği görülmektedir (URL-3 ve URL-4). 
Tablo 4. EM-DAT ile TABB Veri Tabanlarının Deprem Kayıtları

\begin{tabular}{|c|c|c|c|c|c|c|}
\hline \multirow{3}{*}{ İller } & \multicolumn{3}{|c|}{ TABB } & \multicolumn{3}{|c|}{ EM-DAT } \\
\hline & \multicolumn{3}{|c|}{ Deprem } & \multicolumn{3}{|c|}{ Deprem } \\
\hline & Tarih & Ölü Sayıs1 & Yaralı Sayıs1 & Tarih & Ölü Say1s1 & Yaralı Sayıs1 \\
\hline Balıkesir & 24.05 .2014 & 0 & 1 & & & \\
\hline Manisa & 17.09 .2014 & 1 & 0 & & & \\
\hline Kütahya & 19.05 .2011 & 2 & 50 & 19.05.2011 & 3 & 121 \\
\hline \multirow{2}{*}{ Elazığ } & 8.03 .2010 & 41 & 0 & 8.03 .2010 & 51 & 100 \\
\hline & & & & 24.01 .2020 & 41 & 1607 \\
\hline \multirow{4}{*}{ Van } & \multirow{4}{*}{29.10 .2015} & \multirow{4}{*}{0} & \multirow{4}{*}{1} & 23.10. 2011, & 604, & 4152 \\
\hline & & & & 09.11.2011, & 40 & 3 \\
\hline & & & & 23.2.2020, & 9 & 50 \\
\hline & & & & 25.06 .2020 & 0 & 5 \\
\hline Erzurum & & & & 14.06 .2020 & 1 & 35 \\
\hline İstanbul & & & & 26.09 .2019 & 1 & 34 \\
\hline İzmir & & & & 30.10 .2020 & 115 & 1034 \\
\hline Çanakkale & & & & 24.05 .2014 & 0 & 324 \\
\hline Muğla & & & & 21.07 .2017 & 0 & 360 \\
\hline Toplam & & 44 & 52 & & 865 & 7825 \\
\hline
\end{tabular}

Kaynak: (Yazarlar tarafından TABB ve EM-DAT veri tabanlarından elde edilmiştir).

Tablo 4'te bakıldığında TABB veri tabanı tarafından kaydedilip de EM-DAT veri tabanı tarafından kaydedilmeyen depremler olduğu da göze çarpmaktadır. Bunlar Balıkesir, Manisa ve 29.10.2015 tarihinde Van da meydan gelen depremlerdir. Bunun nedeni ise bu depremlerin EM-DAT veri tabanı kriterlerinden en az bir tanesini dahi sağlamamaları olarak gösterilebilir. Buna karşın TABB veri tabanı tarafından hasarın daha az olduğu depremler kayıt altına alınırken hasarın büyük olduğu depremler ise kayıt altına alınmadığı tespit edilmiştir. Bu konuda dikkat çekici olarak gösterilmesi gereken deprem olayları söz konusu yıllar arasında en fazla ölüme ve yaralanmaya neden olan 2011 yılında Van'da meydana gelen depremlerdir. Tabloya bakıldığında günümüze en yakın depremler 30.10.2020 tarihli İzmir ve 24.01.2020 tarihli Elazı̆̆ depremleri olduğu görülmektedir $\mathrm{Bu}$ depremlerde birçok can kaybı meydana gelmiş ve yüzlerce kişi yaralanmıştır. Ancak yine TABB tarafından bu depremler kayıt altına alınmamıştır.

Tablo 4'e bakıldığında hasar göstergesi yüksek olan depremlerin EM-DAT tarafından kayıt altına alındığı, TABB tarafından ise kayıt altına alınmadığı görülmektedir. $\mathrm{Bu}$ da verilerin TABB aracılığıyla alınarak oluşturulan çalışmaların güvenirliğini olumsuz olarak etkilemektedir. Öcal (2019) yaptığı çalışmasında 19002018 yılları arasında ülkemizde meydana gelen afet ve acil durumların olay, ölüm ve yaralanma sayılarını TABB veri tabanından aldığı veriler doğrultusunda belirlemiştir. Buna göre meydana gelen can kaybı açısından $95.541(\% 95,6)$ ile depremler birinci sırada olduğu görülmektedir. Sonrasında sırasıyla $1897(\% 1,9)$ kişi diğer afet ve acil durumlar, $1128(\% 1,1)$ kişi trafik kazaları, 264 (\%0,3) kişi firtına, 256 (\%0,3) kişi patlamalar, 232 $(\% 0,2)$ kişi sel, $202(\% 0,2)$ terör olayları, $143(\% 0,1)$ aşırı kış koşulları, $128(\% 0,1)$ kişi çığ, $57(\% 0,1)$ kişi kentsel yangın, $41(\% 0,0)$ kişi orman yangını, $36(\% 0,0)$ kişi ise heyelandan dolayı hayatını kaybettiğini belirlemiştir. Ancak Türkiye İstatistik Kurumu tarafından açıklanan verilere bakıldığında sadece 2019 yılında kaza yerinde 2524 kişi, kaza sonrası ise 2949 kişinin trafik kazasından dolayı hayatını kaybettiği görülmektedir. Sadece 2009 ile 2019 yılları arasında ise toplamda 11 yılda kaza yerinde ve kaza sonrası 30 gün içerisinde 57568 kişi trafik kazasından öldügü görülmektedir (TÜíK, 2019).

1900-2018 yılları arasında toplamda 119 yılda depremlerin neden olduğu ölümlerin yarsından fazlası 2009-2019 yılları arasında toplamda 11 yılda trafik kazalarından meydana geldiği görülmektedir. Daha kapsamlı bir analiz yapılsa depremler ölüm sayısına göre yapılan sıralamada liderliği trafik kazasına bırakacağı düşünülmektedir. $\mathrm{Bu}$ da TABB veri tabanına ülkemizde meydana gelen afet ve acil durumların istatistikî bilgilerinin eksik girildiğini göstermektedir. Bu eksik girişler nedeniyle ülkemizde meydana gelen afet ve acil durumların çeşitli hasar göstergesi açısından karşılaştırması yapılırken yanlış veya eksik değerlendirmelere neden olabilmektedir. TABB veri tabanı ülkemiz afetlerle ilgili araştırmaların yapılması bakımından çok önemlidir. Ancak bu verilerin düzenli ve eksiksiz olarak TABB sistemine girilmesi büyük önem arz etmektedir. 


\section{SONUÇ}

Veri tabanlarının amacı karar vericilere, uygulayıcılara ve araştırmacılara çalışmalarında yardımcı olmak, toplumun karşı karşıya olduğu risklerin farkında olmasını ve toplum tarafından bu risklerin daha iyi anlaşılmasını sağlamaktır. Bunun yanında afet risk yönetimi kapsamında araştırmacıların ve karar vericilerin ihtiyaç duyduğu meydana gelmiş afetlerin bilgilerinin elektronik ortamda hizmete sunulması amaçlanmıştır. Bu kapsamda oluşturulan TABB ve EM-DAT veri tabanlarının bu çalışma ile temel özellikleri bakımından farklılıkları ve benzerlikleri karşılaştırılarak, incelenmiştir.

EM-DAT veri tabanı dünya çapında en çok atıf alan veri tabalarından bir tanesidir ve TABB veri tabanından daha önce oluşturulmuştur. Hatta TABB veri tabanı, EM-DAT veri tabanı referans alınarak oluşturulmuştur. İster afet ve acil durumların çeşitli etkilerinin nedensel ilişkisini analiz etmek isterse gelecekteki afet olaylarının etkisini tahmin etmek için modelleme yapmak olsun, afet riski araştırmalarındaki temel zorluk, birden çok veri kaynağından yararlanmak ve altta yatan ilişkileri sentezleyip keşfetmektir. Her iki veri tabanı da farklı türlerde afet ve acil durumun ve bunların farklı özelliklerinin kayıtlarını tutması bu açıdan firsat sağladığ 1 düşünülmektedir. Hatta TABB veri tabanı tarafından daha fazla afet ve acil durum türü kayıt altına alındığı görülmektedir. Bunun nedeni ise bazı afet ve acil durumların yöreye özgü olmasından kaynaklandığı söylenebilir.

Her iki veri tabanı da, bu tür afet olaylarının çeşitli sosyo-ekonomik etkilerinin analizini motive eden hem doğal hem de teknolojik afetler hakkında bir takım bilgi sağlamaktadır. Veri tabanları karşılaştııldı̆̆ında veri tabanları tarafından kayıt altına alınan afet türlerinde çok büyük bir farklılık olmamasına rağmen küçük metodolojik farklılıklar olduğu göze çarpmaktadır. EM-DAT uluslararası bir veri tabanıdır ve ülke düzeyinde veri toplama metodolojisine sahipken, TABB veri tabanı ise ulusal bir veri tabanıdır ve il düzeyinde veri toplama metodolojisine sahiptir.

Afetler her iki veri tabanında da genel olarak birbirine benzer veri başlıkları ile kayıt altına alındığı görülmektedir. EM-DAT veri tabanında bulunup TABB veri tabanında bulunmayan veri başlığının olduğu veya bunun tam tersinin de olduğu görülmektedir. Ancak burada dikkat çekici olan veri başlığı ölü ve yaralı sayısıdır. Her iki veri tabanında da bulunmasına rağmen TABB veri tabanında daha kapsamlı olduğu görülmektedir. TABB veri tabanı tarafından ölü ve yaralı sayısı veri başlıkları çocuk, yaşlı, kadın, yetişkin ve erkek şeklinde sınıflandırılmıştır. Bu da afetlerde dezavantajlı grubun ortaya çıkarılmasında büyük önem taşımaktadır.

TABB veri tabanı tarafından kayıt altına alınan afet olay sayısının çok yüksek olduğu görülmektedir. Bunun nedeni olarak ise dahil edilme kriterinin olmaması gösterilebilir. EM-DAT veri tabanı tarafından herhangi bir yerde meydana gelen afetin kayıt altına alınabilmesi için kriterler bulunmaktadır. EM-DAT' veri tabanı tarafından sadece önemli etkiye sahip büyük afet olaylarının kayıt altına alınması, bir ülkede her yıl meydana gelen küçük ve orta ölçekli yüzlerce olayın göz ardı edilmesine neden olmaktadır. TABB veri tabanında ise böyle bir kriter bulunmamaktadır. Bu da küçük ölçekli afetlerinde değerlendirilmesine olanak sağlamaktadır. Bu şekilde küçük ölçekli afetlerinde gözden kaçmasının önüne geçilebileceği düşünülmektedir. Çünkü küçük ölçekli afetlerin ileride büyük bir afete dönüşmeyeceğinin garantisi yoktur. Trafik kazalarında kaza başına düşen ölümler, yaralanmalar veya maddi kayıplar küçük ölçekli olsa da çok fazla sayıda meydana gelmesi nedeniyle yıllık olarak hesaplanan rakamlara bakıldığında diğer afet ve acil durumlardan daha fazla can ve mal kaybı ile yaralanmalara neden olduğu görülmektedir.

Sonuç olarak TABB veri tabanı geniş yelpazede afet ve acil durumları ve bunların özelliklerini kayıt altına alması ve kayıt için herhangi bir kriterin olmaması kapsamlı risk analizlerinin yapılmasına olanak sağladığı söylenebilir. Farklı türlerde afet ve acil durumların kayıt altına alınması önemli olduğu kadar bunların veri tabanına eksiksiz şekilde girilmesi de bir o kadar önemlidir. TABB veri tabanı ile EM-DAT veri tabanı bu açıdan karşılaştırıldığında TABB veri tabanında kayıt için herhangi bir kriter olmamasına rağmen günümüze yakın depremlerin kayıt altına alınmadığı görülmektedir. $\mathrm{Bu}$ da yapılan çalışmaların güvenirliğini ve geçerliliğini olumsuz etkilemektedir. Karar vericilerin ve uygulayıcıların afet ve acil durumlar için afet risk yönetimi kapsamında yanlış stratejiler geliştirmesine neden olabilir. Bu nedenlerle araştırmacıların ortaya koyduğu çalışmaların altlık olduğu düşünüldügünde, ileri dönem risk azaltma çalışmalarının analizlerini, niteliğini, geçerliliğini, doğru kararlar alınmasını ve uygulamaya geçirilmesini doğrudan etkilemektedir. TABB veri tabanı aracılığıyla yapılan araştırmaların güvenirliğinin olumsuz anlamda etkilenmesini önlemek amaciyla yeterli çabanın gösterilmesi ve doğru bilgiye erişimin sağlanması büyük önem arz etmektedir. TABB veri tabanına güncel ve doğru bilgilerin geç girilmesi ya da girilmemesi, araştırmalarda hatalar ortaya çımasına sebep olabileceği gibi bilgi kirliliğine de neden olabilir. 
ŞAHAN, Can ve KAYA, İsmail - Türkiye Afet Bilgi Bankası (TABB) ile EM-DAT Veri Tabanlarının Karşılaştırılarak Değerlendirilmesi

Tüm bu bilgiler eşliğinde çalışma kapsamında geliştirilen öneriler aşağıda listelenmiştir;

- Araştırmaların daha kapsamlı yapılması adına EM-DAT veri tabanı tarafından kayıt altına alınıp TABB veri tabanı tarafindan kayıt altına alınmayan veri setleri (olay adı, afetin bittiği tarih, yerel saat, afetin menşei, 1. ve 2. ilişkili afetler, afetin büyüklük ölçeği ve değeri, afet yardım desteği, ülkenin uluslararası alandan yardım talebi ve zamanı, giriş kriteri, enlem ve boylam, yeniden inşa maliyeti, sigortalı kayıplar, olağanüstü hal ilanı) TABB veri tabanı tarafından da kayıt altına alınmalıdır.

- TABB veri tabanı tarafından kayıt altına alınıp EM-DAT veri tabanı tarafından kayıt altına alınmayan veri setleri (afetin etkilediği alan, zarar gören tarım alanı, büyükbaş hayvan kaybı, ölü ve yaralı sayısı (çocuk, yaşlı, kadın, yetişkin, erkek), kamu, işyeri ve konut (hasarsız, hafif, orta, ağır ve yıkık bina sayısı) EM-DAT veri tabanı tarafindan da kayıt altına alınmalıdır.

- Ölü ve yaralı sayısı veri seti her iki veri tabanında da kayıt altına alınmasına rağmen TABB veri tabanında daha kapsamlı olduğu görülmüştür. Bu veri setleri EM-DAT veri tabanı tarafından da TABB veri tabanında olduğu gibi (ölü ve yaralı sayısı (çocuk, yaşlı, kadın, yetişkin, erkek)) kayıt altına alınmalıdır.

- TABB veri tabanı tarafından ölü sayısı ve kayıp sayısı ayrı ayrı kayıt altına alındığı görülmektedir. Ancak kayıp sayısını, ölü sayısına dahil edilip edilmeyeceği konusunda bir belirsizlik bulunmaktadır. Bu belirsizlik giderilmelidir.

- EM-DAT veri tabanı yaralıları da etkilenenler içerisinde değerlendirmektedir. TABB veri tabanında ise bununla ilgili bir belirsizlik vardır. Bu belirsizlik giderilmelidir.

- TABB veri tabanında afet verilerinin kayıt altına alınırken dikkate alınacak dahil edilme kriterinin olup olmadığ konusunda bir belirsizlik bulunmaktadır. Bu belirsizlik giderilmelidir. Dahil edilme kriterlerinin varlığı küçük ölçekli afet ve acil durumların gözden kaçmasına neden olabileceği de unutulmamalıdır.

- TABB sistemine tüm afet bilgilerinin ve tüm veri setlerinin eksiksiz şekilde girilmesine özen gösterilmelidir.

- TABB veri tabanına sivil toplum kuruluşları (STK), kamu kurum ve kuruluşları, enstitüler, üniversiteler ve özel sektör gibi çeşitli yerlerden bilgi temin edilirken mutlaka karşılaştırmaları kontrolleri yapılmalı ve tutarsızlıklar giderilmelidir.

- TABB veri tabanına diğer kamu kurum ve kuruluşları tarafından sorumlu oldukları afet bilgilerinin yüklenmesine olanak sağlanmalıdır.

- TABB veri tabanına girilen verilerin en yüksek kalite standartlarını karşılamasına özen gösterilmelidir.

- TABB veri tabanında, veri toplama ve kayıpları değerlendirme konusunda kullanılan yöntemler, tüm veri toplama süresi boyunca tutarlı olmalı ve güncel tutulmalıdır.

- TABB veri tabanında ortaya çıkabilecek belirsizlikleri en aza indirmek için, şeffaflık ön planda olmalıdır.

- TABB veri tabanında etkilediği alan kısmına sayısal verilerin girilmesi araştırma yapma imkânı sağlayacaktır.

- TABB veri tabanında afet verileri sisteme girilirken bir standart oluşturulmalı ve insan hataları varsayımına yer verilip verilmeme konusu dikkate alınarak açıklamalarda belirtilmelidir.

- TABB veri tabanı tarafindan tehlike, cinsiyet, yaş, engellilik, gelir ve coğrafyaya gibi farklı kategorilerde de verilerin kaydını yapılması savunmasız grupların tanımlanması açısından büyük önem arz etmektedir.

- EM-DAT veri tabanında olduğu gibi TABB veri tabanının kullanımı kolaylaştıracak kullanımla ilgili yönerge, kullanım kılavuzu ve bunun yanında bir de sözlük eklenmelidir.

- EM-DAT veri tabanına afet ve acil durum olayları kayıt altına alınırken, halihazırdaki giriş kriterlerinin esnekliği sağlanmalıdır.

Sonuç olarak özellikle uluslararası ile ulusal ve bölgesel veri tabanlarının sahip oldukları platformlar dikkate alındığında, temel olarak tehlike ya da afet kavramlarını ilgilendiren farklı terminolojilerin kullanılması nedeniyle veri tabanlarının karşılaştırılmasının çok zor olduğu görülmektedir. 


\section{KAYNAKLAR}

AKYEL, Recai (2007), “Afet Yönetim Sistemi: Türk Afet Yönetiminde Karşılașılan Sorunların Tespit ve Çözümüne İlişkin Bir Araştırma", Yayınlanmamış Doktora Tezi, Çukurova Üniversitesi Sosyal Bilimler Enstitüsü, Adana.

BAŞBUĞ Erkan, BERNA Burçak ve HASGÜL, Etkin (2015), "Turkish Disaster Data Bank”, 7th International Conference of Seismology and Earthquake Engineering (SEE7), Iranian Ministry of Science, Research and Technology (MSRT) and the International Institute of Earthquake Engineering and Seismology (IIEES), Tahran, ss.441-442.

BELOW, Regina, WIRTZ, Angelika and GUHA-SAPIR, Debarati (2009), "Disaster Category Classification and Peril Terminology for Operational Purposes", DIAL Digital Access to Library, URL, http://hdl.handle.net/2078.1/178845 (Erişim Tarihi: 18.04.2021).

CANNON, Terry (2006), “Vulnerability Analysis, Livelihoods and Disasters”, In RISK21-Coping With Risks Due To Natural Hazards İn The 21st Century (Ed. Walter J. Ammann, Stefanie Dannenmann, Laurent Vulliet), CRC Press, London (UK), ss.51-60.

CLIMATE-ADAPT (2021), "EM-DAT, The International Disaster Database", URL: https://climateadapt.eea.europa.eu/metadata/portals/em-dat-the-international-disaster-database-year-of-launch (Erişim Tarihi: 10.04.2021).

DANKERS, Rutger, ARNELL, Nigel W., CLARK, Douglas B., FALLOON, Pete D., FEKETE, Balazs M., GOSLING, Simon N., JENS, Heinke, HYUNGJUN, Kim, YOSHIMITSU, Masaki, YUSUKE, Satoh, TOBIAS, Stacke, YOSHIHIDE, Wada and DOMINIK, Wisser (2014), "First Look At Changes In Flood Hazard In The Inter-Sectoral Impact Model Intercomparison Project Ensemble”, Proceedings of the National Academy of Sciences, S111(9), ss.3257-3261.

DEVOLI, Graziella, STRAUCH, Wilfried, CHÁVEZ, Guillermo and HOEG, Kaare (2007), "A Landslide Database For Nicaragua: A Tool For Landslide-Hazard Management”, Landslide, S.4(2), ss.163-176.

ERKAL, Tevfik ve DEĞERLIYYUR, Mehmet (2009), “Türkiye'de Afet Yönetimi”, Doğu Coğrafya Dergisi, S.14(22), ss.147-164.

GÖKÇE, Oktay, ÖZDEN, Şenay ve DEMİR, Ahmet (2008), Türkiye'de Afetlerin Mekânsal ve İstatistiksel Dağılımı Afet Bilgileri Envanteri, T.C. Bayındırlık ve İskân Bakanlığı Afet İşleri Genel Müdürlüğü Yayını, Ankara.

GÖKÇEKUŞ, Hüseyin, BARLAS, Ceren, ALMUHISEN, Maram ve EYNİ, Nima (2018), "Doğal ve İnsan Kaynakl Afetler, Sonuçlarl ve Afet Yönetimi”, URL, http://www.iusarc.org/wpcontent/uploads/2020/11/Dogal-ve-Insan-Kaynakli-Felaketler-Sonuclari-ve-Afet-Yonetimi.pdf (Erişim Tarihi: 08.04.2021).

GUHA-SAPİR, Debarati, HARGITT, David and HOYOIS, Philippe (2004), Thirty Years of Natural Disasters 1974-2003, The Numbers. Presses Univ. De Louvain Press, Wallonia (Belgium)..

GÜLER, Hasan Hüseyin (2008), "Zarar Azaltmanın Temel Illkeleri”, Afet Zararlarını Azaltmanın Temel İlkeleri (Ed. Mikdat Kadığlu, Emin Özdamar), JICA Türkiye Ofisi Yayını, Ankara, ss.35-50.

HAMZAÇEBI, Gülşah, NURLU, Murat, AKIN, Demir ve KOÇ, Nurcan (2007), "Ulusal Afet Arşiv Sistemine Ayrıntılı Bir Bakış”, Altıncı Ulusal Deprem Mühendisliği Konferansı Bidiriler Kitabı, Maya Basın Yayın, İstanbul, ss.173-184.

IŞIK, Özden, AYDINOĞLU, Hakan Mehmet, KOÇ, Selma, GÜNDOĞDU, Oğuz, KORKMAZ, Gülcan ve AY, Asime (2012), "Afet Yönetimi ve Afet Odaklı Sağlık Hizmetleri”, Okmeydanı Tıp Dergisi, S.28(Ek Say1 2), ss.82-123.

İLGEN, Hülya (1995), “Afetlerin Yaşam Üzerine Etkileri ve Önleme Çalışmaları”, Türkiye Mühendislik Haberleri, S.379, ss.91-94.

KADIOĞLU, Miktat (2008), "Modern, Bütünleşik Afet Yönetimin Temel Illkeleri”, Afet Zararlarının Azaltmanın Temel İlkeleri (Ed. Mikdat Kadıŏlu, Emin Özdamar), JICA Türkiye Ofisi Yayını, Ankara, ss.1-34. 
ŞAHAN, Can ve KAYA, İsmail - Türkiye Afet Bilgi Bankası (TABB) ile EM-DAT Veri Tabanlarının Karşılaştırllarak Değerlendirilmesi

KADIOĞLU, Miktat. (2011), Afet Yönetimi Beklenilmeyeni Beklemek En Kötüsünü Yönetmek, T.C. Marmara Belediyeler Birliği Yayını, İstanbul.

KARAASLAN, Ahmet (2015), “Amerika Birleşik Devletleri’ndeki Afet Yönetimi Ile Türkiye'deki Afet Yönetiminin Karşılaştırılması”, Yüksek Lisans Tezi, Sakarya Üniversitesi Sosyal Bilimler Enstitüsü, Sakarya.

KEÇİCİ, Muzaffer (1994), “Doğal Afetlerde Bulaşıcı Hastalıklar ve Çevre”, Bayındırlık ve İskân Bakanlı̆ğ İle Belediyeler Dergisi, S.8, ss.24-47.

KUNDAK, Seda ve KADIOĞLU, Miktat (2011), İlk 72 Saat, AFAD Yayınları, Ankara.

LI, Guoqing, ZHAO, Jing, MURRAY, Virginia, SONG, Carol and ZHANG, Lianchong (2019), "Gap Analysis on Open Data Interconnectivity For Disaster Risk Research", Geo-Spatial Information Science, S.(22)1, ss.45-58.

MACİT, İrfan (2019), "Bütünleşik Afet Yönetiminde Sendai Çerçeve Eylem Planının Beklenen Etkisi”, Doğal Afetler ve Çevre Dergisi, S.5(1), ss.175-186.

OCAL, Adem (2019), "Natural Disasters in Turkey: Social and Economic Perspective", International Journal of Disaster Risk Management, S.1(1), ss.51-61.

ÖZCEYLAN, Dilek ve COŞKUN, Erman (2012), "Van Depremi Sonrası Yaşananlar Işı̆ğında Sosyal ve Ekonomik Zarar Görebilirlik Çalışmalarının Önemi”, Eskişehir Osmangazi Üniversitesi İktisadi ve İdari Bilimler Dergisi, S.7(1), ss.167-186.

ÖZEŞEN ÇOLAK, Sibel (2017), Risk ve Kriz Yönetimi, Acil Yardım ve Afet Yönetimi Lisans Tamamlama Programı, İstanbul Üniversitesi Açık ve Uzaktan Eğitim Fakültesi Yayını, İstanbul.

ÖZMEN, Bülent ve ÖZDEN, Tolga Ali (2013), “Türkiye'nin Afet Yönetim Sistemine Illişkin Eleştirel Bir Değerlendirme”, İstanbul Üniversitesi Siyasal Bilgiler Fakültesi Dergisi, S.49, ss.1-28.

SENA, Lelisa ve WOLDMİCHAEL, Kifle (2006), "Disaster Prevention And Preparedness", Ethopia Public Heal Train Initiat, S.1, ss.1-80.

TAŞTAN, Bekir ve AYDINOĞLU, Arif Çağdaş (2015), “Çoklu Afet Risk Yönetiminde Tehlike ve Zarar Görebilirlik Belirlenmesi İçin Gereksinim Analizi”, Marmara Coğrafya Dergisi, S.31, ss.366-397.

TÜIK - TÜRKIYE İSTATISTIK KURUMU (2019), Karayolu Trafik Kaza İstatistikleri, TÜIK Yayınları, Ankara, https://data.tuik.gov.tr/Bulten/Index?p=Karayolu-Trafik-Kaza-Istatistikleri-2019-33628 (Erişim Tarihi: 03.04.2021).

UN - UNITED NATIONS DEPARTMENT OF HUMANITARIAN AFFAIRS (1992), Internationally Agreed Glossary of Basic Terms Related to Disaster Management, (DNA/93/36) United Nations Publisher, Geneva.

UNDRR - UNITED NATIONS OFFICE FOR DISASTER RISK REDUCTION (2015), Global Assessment Report on Disaster Risk Reduction, https://www.preventionweb.net/understanding-disaster-risk/keyconcepts/disaster-risk-reduction-disaster-riskmanagement?utm_campaign=PreventionSavesLives\&utm_source=Twitter (Erişim Tarihi: 29.04.2021).

UNISDR - UNITED NATIONS INTERNATIONAL STRATEGY FOR DISASTER REDUCTION (2009), 2009 UNISDR Terminology on Disaster Risk Reduction, https://www.unisdr.org/files/7817_UNISDRTerminologyEnglish.pdf (Erişim Tarihi: 29.04.2021).

URAL, Derin, ÖZMEN, Bülent, ÇOBAN, Hasan ve ARLI YILMAZ, Selen (2014), Afet Yönetiminde Etkinlik Özel İhtisas Komisyonu Raporu, T.C. Kalkınma Bakanlığı Yayını, Ankara.

URL-1 (2021), "Türkiye Afet Bilgi Bankast Projesi”, URL, http://www.saldemsoft.net/AnaIcerik/78/tcbasbakanlik-afet-ve-acil-durum-yonetimi-baskanligi-turkiye-afet-bilgi-bankasi-web-ve-mobil-uygulamaprojesi-tabb/ (Erişim Tarihi: 29.04.2021).

URL-2 (2021), "Afet ve Acil Durum Yönetim Başkanlığı, Türkiye Afet Bilgi Bankası (TABB)”, URL, https://www.afad.gov.tr/tabb-turkiye-afet-bilgi-bankasi (Erişim Tarihi: 29.04.2021).

URL-3 (2021), “Afet Acil Durum Veri Tabanl -Emergency Disaster Database (EM-DAT)”, URL, http://www.emdat.be / (Erişim Tarihi: 29.04.2021). 
URL-4 (2021), “Afet ve Acil Durum Yönetim Başkanlığı, Türkiye Afet Bilgi Bankası Portalı (TABB)”, URL, https://tabb.afad.gov.tr/ (Erişim Tarihi: 29.04.2021).

URL-5 (2021), "Türkiye İstatistik Kurumu Afet Istatistikleri”, URL, https://www.resmiistatistik.gov.tr/detail/subject/afet-istatistikleri (Erişim Tarihi: 29.04.2021).

WACH, Elise and RICHARD, Ward (2013), "Learning About Qualitative Document Analysis", URL, https://opendocs.ids.ac.uk/opendocs/bitstream/handle/20.500.12413/2989/PP\%20InBrief\%2013\%20QDA \%20FINAL2.pdf?sequence=4\&isAllowed=y (Erişim Tarihi: 27.03 .2021$)$.

WIRTZ, Angelika, KRON, Wolfgan, LÖW, Petra and STEUER, Markus (2014), "The Need For Data: Natural Disasters and The Challenges of Database Management", Natural Hazards, S.70, ss.135-157.

YAVAŞ, Hikmet (2005), Doğal Afetler Yönüyle Türkiye'de Belediyelerde Kriz Yönetimi (İzmir Örneği), Orion Yayınevi, Ankara.

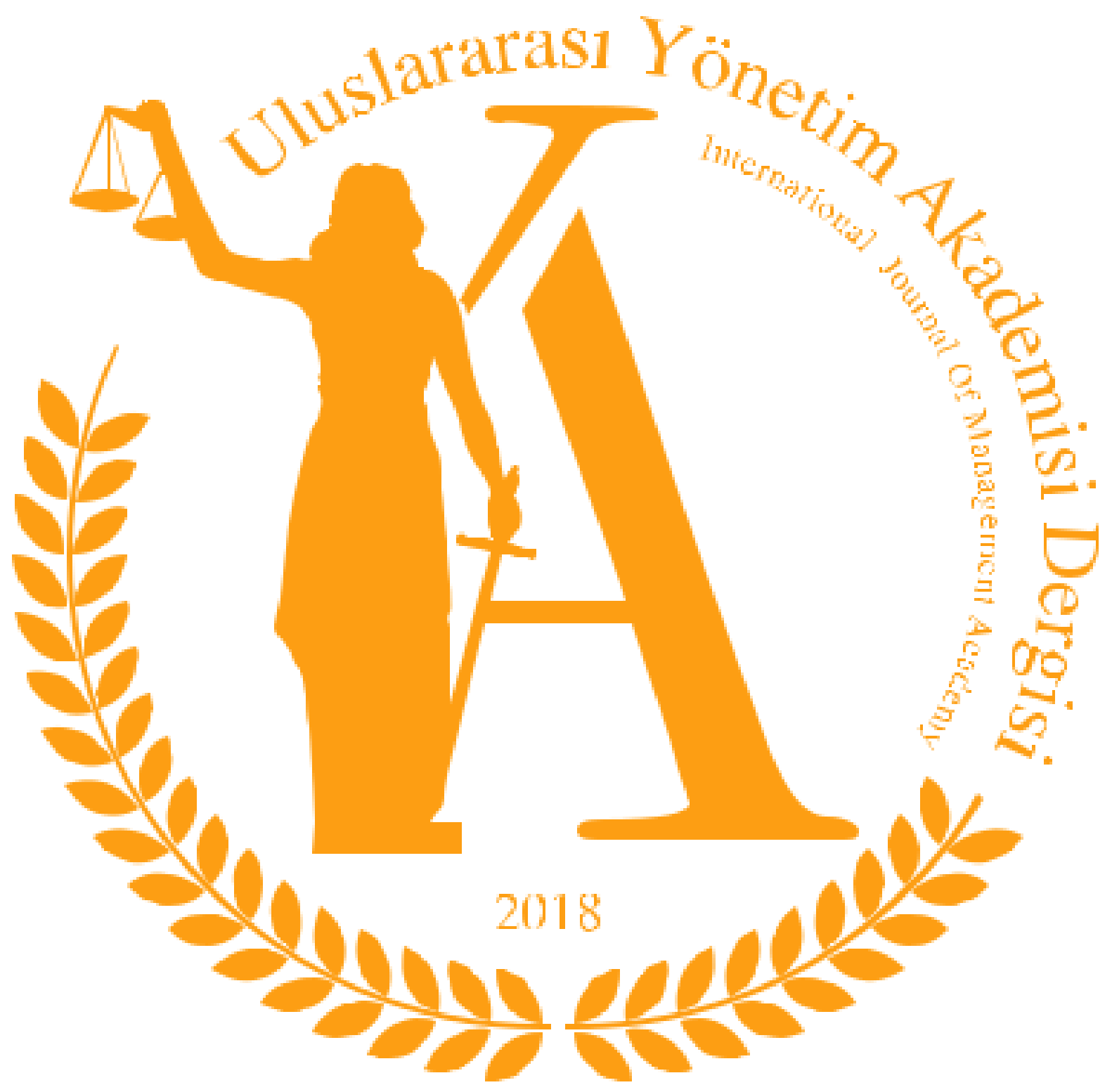

